\title{
Children's Gender Identity in Lesbian and Heterosexual Two-Parent Families
}

\author{
Henny Bos • Theo G. M. Sandfort
}

Published online: 15 October 2009

(C) The Author(s) 2009. This article is published with open access at Springerlink.com

\begin{abstract}
This study compared gender identity, anticipated future heterosexual romantic involvement, and psychosocial adjustment of children in lesbian and heterosexual families; it was furthermore assessed whether associations between these aspects differed between family types. Data were obtained in the Netherlands from children in 63 lesbian families and 68 heterosexual families. All children were between 8 and 12 years old. Children in lesbian families felt less parental pressure to conform to gender stereotypes, were less likely to experience their own gender as superior and were more likely to be uncertain about future heterosexual romantic involvement. No differences were found on psychosocial adjustment. Gender typicality, gender contentedness and anticipated future heterosexual romantic involvement were significant predictors of psychosocial adjustment in both family types.
\end{abstract}

Keywords Gender identity · Sexual questioning ·

Psychosocial adjustment $\cdot$ Lesbian families

\section{Introduction}

The aim of this study is to assess whether dimensions of gender identity and anticipated future heterosexual involvement of

\section{H. Bos $(\bowtie)$}

Faculty of Social and Behavioural Sciences,

Department of Education, University of Amsterdam,

Amsterdam, The Netherlands

e-mail: H.M.W.Bos@uva.nl

T. G. M. Sandfort

HIV Center for Clinical and Behavioural Studies, New York State

Psychiatric Institute and Columbia University,

New York, NY, USA children in lesbian parent families differ from children in heterosexual parent families. The concern that gender development might be thwarted by growing up in a lesbian family has been put forward as a major argument against lesbian families (Clarke 2002). Whether gender development is thwarted has hardly been studied. Available studies can be criticised for using a limited operationalization of gender by only studying children's masculine and feminine personality traits, or aspirations for traditionally masculine and feminine occupations (Stacey and Biblarz 2001), while other relevant dimensions of gender identity can be distinguished.

In this study we used a broader, multidimensional conceptualization of gender identity developed by Egan and Perry (2001). This conceptualization encompasses selfperceptions of gender typicality, contentment with one's gender, experienced pressure for gender conformity, and attitudes towards the other gender. Following Egan and Perry (2001), we also examined children's anticipation of future heterosexual romantic involvement ('sexual questioning'). The latter has not been examined before in children in lesbian families, although some studies have shown that young adults who grew up in a lesbian family were more likely to consider or were more frequently involved in a same-sex relationship (Golombok and Tasker 1996). By using a multidimensional approach of gender identity and including sexual questioning, our research provides a broader view on children's gender development in lesbian families. Elaborating on studies of the psychosocial adjustment of children in lesbian families, we furthermore assessed how gender identity and sexual questioning are related to psychosocial adjustment. We collected data directly from 63 children in lesbian parent families and 68 children in heterosexual parent families instead of from parents, on which this type of research usually relies. 
Whether lesbian women are fit to parent children and should have the right to do so is a contested issue in social, religious and political debates (Clarke 2001; Clarke and Kitzinger 2004; Sandfort 2000). According to Golombok (2000) and Stacey and Biblarz (2001) the most frequently mentioned argument against lesbian women who raise children is that growing- up in a household with two (lesbian) mothers will impair children's psychosocial adjustment (see for overview: Golombok 2000; Stacey and Biblarz 2001). Another argument is that growing-up with two mothers will negatively influence the children's gender identity (a person's concept of him- or herself as male and female), gender role behaviour (behaviours and attitudes considered appropriate for males or females in Western societies), and sexual orientation (a person's sexual attraction toward a person of the other or the same gender) (see for overview: Golombok 2000). Although there is growing evidence that there are no differences in psychosocial adjustment between children raised in lesbian families and those raised in heterosexual families - as expressed in the so-called 'no difference consensus'-there is disagreement about whether gender development differs between children in these two family types (Stacey and Biblarz 2001).

Researchers who studied gender identity (one aspect of gender development) of children in lesbian families have assessed children's personality traits or occupational aspirations or activities preferences. These studies show contradictory findings (MacCallum and Golombok 2004). MacCallum and Golombok (2004), for example, found that boys growing up in lesbian families or in single mother families showed more feminine personality traits than boys in two-parent heterosexual families. Other studies, however, did not find such differences (Golombok et al. 1983). Studies focusing on children's aspiration to traditionally masculine or feminine occupations and activities also showed contradictory findings. Green et al. (1986), for example, found that daughters (but not sons) in lesbian families have a stronger preference for non-traditional gender occupations or activities than girls in heterosexual families. This in contrast to other studies, in which such differences were not found (Brewaeys et al. 1997; Fulcher et al. 2008; Golombok et al. 2003).

Sexual orientation of lesbian offspring, as another aspect of gender development, has also been assessed in previous studies. Young adults who were raised by a lesbian mother (but had been born in the context of the mother's heterosexual relationship before she self-identified as lesbian) did not more frequently identify as lesbian, gay or bisexual (most of them identified as heterosexual) compared to those raised in heterosexual families (Tasker and Golombok 1997). Young adults raised by lesbian mothers, however, seemed more likely than those raised by heterosexual parents to consider a same-sex relationship as a possible alternative and were also more likely to engage in same-sex relationships (Golombok and Tasker 1996; Tasker and Golombok 1997).

There are various perspectives on the role of parents in the development of children's gender development that could help to understand differences between children in lesbian and heterosexual families. Social learning theorists (e.g. Bandura 1977) stress the importance of parents and argue that the development of a child's sense of being a boy or a girl depends on observing and imitating the behaviour and gender-related attitudes of his or her parents. A metaanalysis carried out by Tenenbaum and Leaper (2002) showed that parents do have an impact on their children's gender-related thinking. Parents who hold stronger gender stereotypes and traditional attitudes towards women, for example, are more likely to have children who hold strong traditional gender role beliefs (Lippa 2002). Recent research showed that lesbian mothers' attitudes towards the gender role behaviour of their children are more liberal compared to heterosexual parents (Fulcher et al. 2008). If lesbian mothers are less sex-stereotyped than heterosexual mothers and provide an environment that is not sexstereotyped, then it might be expected that children brought up by two women develop less strong stereotypical gender behaviour repertoires and identities (Baumrind 1995; Stacey and Biblarz 2001). The greater involvement of young adults from lesbian families in same-sex relationships is also explained from a social learning theory perspective, i.e. these young people feel freer to engage in same-sex relations because their lesbian mothers are less likely to discourage them from doing so (Golombok and Tasker 1996).

There are also theories that argue that parenting has a minor impact on children's gender development. If gender identity is, for example, primarily biologically determined by genetic influences (Iervolino et al. 2002) or prenatal sex hormones (Collaer and Hines 1995), the influence of parents will be small. From the perspective of cognitivedevelopmental theory, the role of parents in a child's gender identity is also minor. According to this theory, gender schemas (organized knowledge and beliefs about gender in the wider social environment) play an important role in gender development and children have an active role in acquiring these gender schemas (Martin 2000). Children integrate information about their gender from their wider social environment, especially their peers, and actively construct for themselves, based on this information, what it means to be a boy or a girl (Maccoby 1998; Martin et al. 2004).

Gender identity being a multidimensional construct, the currently available studies can be criticised for their limited perspective by mainly focussing on masculine and feminine 
personality traits or traditionally masculine and feminine occupational aspirations. For this study we adopted a multidimensional conceptualization of gender identity as developed by Egan and Perry (2001). These authors define gender identity as 'the collection of thoughts and feelings one has about one's membership of it' (Carver et al. 2003; page 95) and conceptualize gender identity as: (1) the feeling that one is a typical member of one's gender category (gender typicality), (2) being happy with one's assigned gender (gender contentedness), (3) the pressure from parents and peers to conform to gender stereotypes (felt pressure to conform), and (4) the feeling that one's gender is superior to the other gender (intergroup bias). Egan and Perry (2001) showed that these components of gender identity are associated with psychosocial adjustment, especially global self-worth and social competence: children with a stronger sense of gender typicality and gender contentedness have more favourable global selfworth and social competence, while felt pressure to conform and intergroup bias are associated with lower global self-worth and social competence.

Egan and Perry (2001) also developed an instrument to measure children's anticipated future heterosexual romantic involvement, which they called 'sexual questioning'. This measure is an alternative for a more direct measure of sexual attraction which might not yet be opportune or be too intrusive for preadolescents, eliciting undue discomfort, distress or defensive responding. This instrument assesses how confident children are that in the future they would experience attraction to someone of the other gender and participate in romantic relationships and roles with someone of the other gender. Egan and Perry found that children (mean age 11 years old) who had doubts about future heterosexual romantic involvement reported lower global self-worth and lower social competence than other children. It is unclear, however, whether these relations also exist in children in lesbian families. We furthermore assessed whether the associations between sexual questioning but also gender identity (gender typicality, gender contentedness, felt pressure to conform to gender stereotypes, intergroup bias) on the one hand and global selfworth and social competence on the other hand are different for children in lesbian families compared to those in heterosexual families.

The current study was conducted in the Netherlands, which differs in important ways from countries such as the UK and the USA where most studies about children in lesbian families have been carried out. First of all, the discussion about lesbian parenthood is more advanced. This debate started in the mid- eighties with a discussion about same-sex marriage (Vonk 2004). In 2001 the Netherlands became the first country to legalize same-sex marriages. This early legalization can be seen as an indication of the high level of social acceptance of homosexuality and samesex parenting. Compared to other European countries, the Netherlands seems to be the most accepting of same-sex marriage. The Netherlands tops the list with $82 \%$ of participants in favor of same-sex marriage, compared to $46 \%$ and $40 \%$ in the UK and the USA, respectively (European Commission 2006; Gallup Poll 2009). The proposition that homosexual couples should be authorized to adopt children also receives a much higher levels of agreement in the Netherlands (69\% versus 33\% in the UK). Other studies also demonstrated that the public opinion in the Netherlands is more favourable towards homosexuality, same-sex marriage, and lesbian and gay parenthood, compared to that in the UK and the USA (Hofstede 1998; Kelley 2001; Sandfort et al. 2008; Van de Meerendonk and Scheepers 2004; Van de Meerendonk et al. 2003). The legal position of Dutch children of same-sex couples, however, still differs though from that of children of different-sex couples. For example, a child born to a woman who is married to another woman, does not automatically get that second woman as its legally second parent; this in contrast to children born in a heterosexual marriage (Committee on Lesbian Parenthood and Intercountry Adoption 2008).

Another major difference, and potentially related to the first, concerns the social role differentiation between the genders. This differentiation is much smaller in the Netherlands compare to the UK and the USA (Hofstede 1998); the Netherlands scores much lower on Hofstede's Masculinity dimension, indicating that the values of men and women differ less, that women are treated more equally, and that harmony and nurturing are more valued than competition. In the last wave of the World Value Survey (2005) people were asked how strongly they agree or disagree with the statement that "A university education is more important for a boy than for a girl" and almost 50\% of the Dutch participants said that they strongly disagree with this; this in contrast to $31.6 \%$ of the participants in the UK and $33.7 \%$ in the USA.

An important predictor of negative values regarding attitudes towards gender equality and homosexuality is religiousness (Lubbers et al. 2009; Whitley 2009). In this respect the Netherlands also differs from the UK and the USA.. When people were asked in the World Value Survey (2005) to indicate how important religion is in their life, $13.1 \%$ of the Dutch, $20.4 \%$ of the British and $46.8 \%$ of the Americans said "very important." These differences in importance of religion and social acceptance of homosexuality, same-sex marriage, and lesbian and gay parenthood have influence on how children in lesbian families in different countries develop. The more accepting cultural context seems to positively affect children who grow up in same-sex families: In comparison with children of lesbian parents in the USA, Dutch children of lesbian parents were 
shown to experience less stigma and fewer emotional and behavioral problems (Bos et al. 2008). Although not the focus of this study, it is also to be expected that Dutch children's attitudes regarding gender identity are more fluid than the attitudes of children in the UK and the US.

\section{Hypotheses of the Current Study}

Assuming that lesbian and heterosexual parents offer children different gender-related models and attitudes towards gender (Fulcher et al. 2008; Stacey and Biblarz 2001), we expected to find differences between children in lesbian families and those in heterosexual families with respect to most of the aspects of gender identity as conceptualization by Egan and Perry (2001). More specifically, we hypothesized that children in planned lesbian families would be less likely to experience themselves as typical members of their gender category (gender typicality); to experience less pressure to conform to traditional gender role expectations (especially from their parents); and to experience their own gender as superior (intergroup bias). We did not expect differences in gender contentedness. We also assessed children's sexual questioning (anticipated future heterosexual romantic involvement) and expected children in lesbian families to have less strong expectations of future heterosexual romantic involvement (higher sexual questioning). Regarding children's psychosocial adjustment (conceptualized in this study as global self-worth and social competence), we expected no effect of family type (lesbian families versus heterosexual families).

In addition, we hypothesized that negative associations between atypical gender identity and sexual questioning, and global self-worth and social competence are less strong for children in lesbian families compared to children in heterosexual families. This hypothesis is based on the assumption that lesbian mothers provide an environment in which children feel freer to explore their gender identity and might acquire less traditional gender norms.

\section{Method}

Procedure

\section{Recruitment}

The present study was a follow-up to an earlier study ('Parenting in planned lesbian families') in which we compared planned lesbian and heterosexual two-parent families on parental behaviour and the experience of parenthood using parental self-reports and observations
(Bos et al. 2004, 2007). For this initial study we recruited lesbian families in several ways, namely by consulting patient files of the Medical Center for Birth Control, by approaching people who were on the mailing list of a Dutch interest group for gay/lesbian parents, and by presenting information about the study during meetings organized by Dutch healthcare centres about lesbian and gay parenthood. In the original study, a control group of heterosexual families was drawn from the population register of two cities and through primary schools. The children in both family types were between 4 and 8 years old at the time the data for this first study were collected. All parents in our first study were informed about the follow-up study and gave us permission to approach them again.

\section{Response}

All families that had participated in the original study (100 planned lesbian families and 100 heterosexual families) received a written invitation to participate in the follow-up. Of the 100 planned lesbian families in the original study, $63 \%$ indicated that they were willing to participate; of the 100 original heterosexual families, $42 \%$ indicated their willingness to participate. In order to have a similar number of children in the heterosexual control group, we contacted an additional 90 heterosexual families through a primary school. Of these families, $26(28.8 \%)$ were willing to participate. These 26 heterosexual families did not differ significantly on social demographic variables from the 42 heterosexual families recruited from the earlier study. The lesbian and heterosexual families that did not participate in the current study did not differ from the families that did participate in the current study on social demographic variables, including degree of urbanization of the place where the families lived, age and gender of the target child, age and educational level of the parents, and duration of the parents' relationship. Nor did they differ on measures of the quality of parenting, parent-child interaction or problem behaviour of the child as assessed in the original study.

\section{Data Collection}

Data were collected by means of questionnaires that were administered during a 1-hour session with each child at the child's home. Following the method used by Egan and Perry (2001), the first author or one of her collaborators read the questionnaire items to the child and then recorded the child's answers.

\section{Research Participants}

The mean age of the participating children in the lesbian families did not differ significantly from that of the 
children in the heterosexual families (lesbian families: $M=$ 9.93 years, $S D=1.48$, heterosexual families: $M=$ 9.99 years, $S D=1.32$ ). In both family types the age of the children ranged between 8 and 12 years old, and most children $(62.6 \%)$ were between 10 and 12 years old. The proportions of boys and girls in the two family types (32 boys and 31 girls in the lesbian family group, and 34 boys and 34 girls in the heterosexual family group) also did not differ significantly.

Most parents in both family groups were highly educated (85.3\% of all respondents held a higher professional or academic degree), and there was no significant difference in level of education between lesbian and heterosexual parents ( $87.1 \%$ of the lesbian couples and $82.5 \%$ of the heterosexual parents had a higher professional or academic degree). Most families lived in urban areas, and again no significant difference was found regarding place of residence between both family types $(90 \%$ of the lesbian families and $98 \%$ of the heterosexual families lived in urban areas). Also the duration of the intimate relationship between the partners in the lesbian families did not differ from that of the relationship between the partners in heterosexual families: the lesbian couples had been together for an average of 19.20 years $(S D=4.19)$, and the heterosexual couples for an average of 18.87 years $(S D=4.94)$. The mean age of the lesbian mothers $(M=45.07, S D=3.29)$ differed, however, from that of the heterosexual parents $(M=43.33, S D=4.36)$, $F(1,261)=5.16, p<.05$. There was also a significant difference regarding the number of children in the family: the mean number of children in the lesbian families $(M=1.94, S D=.53)$ was smaller than that in the heterosexual families $(M=2.51, S D=.92), F(1,130)=19.11, p<.001$.

\section{Measure}

\section{Gender Identity}

We used the multidimensional gender identity questionnaire developed by Egan and Perry (2001) to assess gender typicality, gender contentedness, felt pressure to conform (from parents and peers), and intergroup bias. In the original instrument, the items on these scales are formulated as bipolar statements: the child first has to select the statement that describes him or her in the best way and then report whether the description is 'sort of true' or 'really true' of him or her. Van den Bergh and Marcoen (1999) showed that this response format is too complex for younger children. We therefore changed the answering format: children were asked to rate on a 4-point scale 'how true of you' each statement was $(1=$ not true at all; $4=$ very true)(see Appendix). For each of the five scales a mean score was calculated. The examples below are taken from the girls' version of the questionnaire.
The Gender Typicality scale assessed the children's' feeling that they were typical members of their gender category (six items, e.g. 'I think I'm a good example of being a girl'), while the Gender Contentedness scale assessed the feeling of being happy about their gender (six items, e.g. 'I like being a girl')(see for both scales Appendix). A principal component analysis resulted in a two-factor solution, explaining $29 \%$ (gender typicality) and $17 \%$ (gender contentedness) of the variance. Cronbach's alphas for Gender Typicality and Gender Contentedness were .78 and .70 , respectively.

The degree to which children felt pressure from their parents and peers to conform to gender stereotypes was assessed with four items related to pressure from parents and four items related to pressure from peers (e.g. 'I think that my parents/peers would be upset if I told them that I want to play with boys' toys'). Principal component analysis was performed on these items. As expected two factors were extracted that explained $40 \%$ (pressure from parents) and $15 \%$ (pressure from peers) of the variances. Cronbach's alphas were .66 and .72 for pressure from parents and pressure from peers, respectively.

Intergroup Bias, the degree to which children feel that their own gender is superior to the other gender, was assessed with eight items (e.g. 'I think girls are more truthful than boys'); a high score indicates more bias. Cronbach's alpha was .76.

\section{Sexual Questioning}

To measure children's expectations of future heterosexual romantic involvement, we used the Sexual Questioning scale developed by Egan and Perry (2001). As with the aforementioned scales, we simplified the response format. Children were asked to rate on a 4-point scale how confident they were that in the future they would 'marry a man', 'have a family together with a man', 'live together with a man', 'have a child together with their husband' and 'be in love with a man' $(1=$ not confident at all; $4=$ very confident)(see Appendix). In the boys' version, 'man' and 'husband' were replaced by 'woman' and 'wife'. Answer categories were recoded: high scores indicate that respondents were less certain about future heterosexual attractions and relationships; and mean scores were calculated. As in studies with similar age groups, the scale's Cronbach's alpha in our study was sufficient $(\alpha=.77)$.

\section{Psychosocial Adjustment}

Two dimensions of psychosocial adjustment were measured: global self-worth and social competence. Both were assessed by using subscales of the Dutch version of the Harter Perceived Competence Scale for Children (PCSC; 
van den Bergh and Marcoen 1999). Each scale consists of seven items. In the original PCSC, as developed by Harter (1985), the items are formulated in a similar way (with bipolar statements) as the original multidimensional gender identity questionnaire. Again, because of the complexity of the response format we reformulated the answer categories: children were asked to rate on a 4-point scale whether the labels or statements were true of them $(1=$ not true at all; 4 = very true). Examples of statements are 'being happy' (Global Self-Worth) and 'being popular among classmates' (Social Competence). For both scales mean scores were calculated. Cronbach's alphas were .77 (Global Self-Worth) and .66 (Social Competence).

\section{Results}

Results are reported in two sections. First we report findings regarding the comparison in gender identity (gender typicality, gender contentedness, felt pressure to conform to gender stereotypes, intergroup bias), expectations of future heterosexual romantic involvement (sexual questioning) and psychosocial adjustment (global self-worth and social competence) between children in lesbian families and heterosexual families. In the second section we report on whether the associations between gender identity and sexual questioning on the one hand and global self-worth and social competence on the other hand are different for children in lesbian families compared to those in heterosexual families.

\section{Differences in Gender Identity, Expectations of Future Heterosexual Romantic Involvement, and Psychosocial Adjustment}

We hypothesized that children in lesbian families would differ from their counterparts in heterosexual families with respect the studied gender identity aspects (except for gender contentedness) and also would differ on sexual questioning but not on psychosocial adjustment. To test this hypothesis a 2 (child gender: 1 = boy; 2 = girl) by 2 (family type: 1 = lesbian family; 2 = heterosexual family) multivariate analysis of variance (MANOVA) was conducted with children's report of gender identity (gender typicality, gender contentedness, felt parental pressure, felt peer pressure, intergroup bias), sexual questioning, and psychosocial adjustment (global self-worth and social competence) as the dependent variables (see Table 1 for means and standard deviations).

A significant multivariate main effect was found for family type (Wilks's $\lambda=.84, F(8,130)=2.87, p<.001$ ) and gender of the child (Wilks's $\lambda=.60, F(8,130)=10.10, p<.001)$. The interaction of family type $\mathrm{x}$ gender of the child was not significant, Wilks's $\lambda=.94, F(8,130)=.97, p>.05$.
Family Type

The children in each of the two family types were not significantly different from one another on gender typicality, gender contentedness and felt pressure from peers. A main effect of family type, however, did emerge on intergroup bias and parental pressure to conform to gender stereotypes. Children in lesbian families were less likely to regard their own gender as superior (intergroup bias). They also reported less parental pressure to conform to gender stereotypes than children in heterosexual two-parent families.

A main effect of family type was found for anticipated future heterosexual romantic involvement: compared to those in heterosexual families, children in lesbian families were less certain that in the future they would experience heterosexual attraction and engage in heterosexual relationships.

Regarding global self-worth and social competence, no significant differences were found between children in lesbian families and heterosexual families.

\section{Gender of the Target Child}

There was a significant main effect of gender of the child on all studied aspects of gender identity. Compared to girls, boys showed higher levels of gender typicality and felt more pressure from parents and peers to conform to gender stereotypes. Boys, however, scored less high on gender contentedness and also less high on intergroup bias. No significant main effect of gender of the child was found on expectations of future heterosexual romantic involvement; nor on global self-worth and social competence.

\section{Interaction Effect}

As described above, no significant interaction effect of family type $\mathrm{x}$ gender of the child was found in MANOVA.

Family Type, Gender Identity and Sexual Questioning, and Psychosocial Adjustment

We hypothesized that the negative associations between atypical gender identity and sexual questioning, and global self-worth and social competence would be less strong for children in lesbian families compared to children in heterosexual families. To test this hypothesis we conducted two hierarchical regression analyses; one for global selfworth and one for social competence. Gender of the child and family type were entered in Step 1, the studied gender identity variables (gender typicality, gender contentedness, felt parental pressure, felt peer pressure, intergroup bias) and sexual questioning were entered in Step 2, and the 
Table 1 Means (standard deviations) of children's reports of gender identity and sexual questioning.

\begin{tabular}{|c|c|c|c|c|c|c|c|c|c|}
\hline & \multicolumn{3}{|c|}{ Children of lesbian parents } & \multicolumn{3}{|c|}{ Children of heterosexual parents } & \multirow{2}{*}{$\begin{array}{l}\text { Gender effects } \\
F(1,130)=\end{array}$} & \multirow{2}{*}{$\begin{array}{l}\text { Family type } \\
\text { effects } \\
F(1,130)=\end{array}$} & \multirow{2}{*}{$\begin{array}{l}\text { Interaction } \\
\text { effects } \\
F(1,130)=\end{array}$} \\
\hline & Boys & Girls & Total & Boys & Girls & Total & & & \\
\hline \multicolumn{10}{|l|}{ Gender identity } \\
\hline Gender typicality $^{\mathrm{a}}$ & $2.88(.53)$ & $2.64(.64)$ & $2.76(.60)$ & $2.84(.55)$ & $2.53(.61)$ & $2.68(.60)$ & $7.20 * *$ & .64 & .11 \\
\hline Gender contentedness ${ }^{\mathrm{b}}$ & $1.88(.50)$ & $2.21(.53)$ & $2.05(.53)$ & $1.76(.40)$ & $2.17(.63)$ & $1.97(.57)$ & $16.06^{* * *}$ & .83 & .27 \\
\hline Parental pressure ${ }^{\mathrm{c}}$ & $1.54(.61)$ & $1.37(.42)$ & $1.46(.53)$ & $1.85(.74)$ & $1.53(.51)$ & $1.69(.65)$ & $5.69^{*}$ & $5.14^{*}$ & .52 \\
\hline Peer pressure ${ }^{\mathrm{d}}$ & $2.73(.85)$ & $1.86(.45)$ & $2.30(.81)$ & $2.76(.65)$ & $2.05(.58)$ & $2.40(.71)$ & $48.21 * * *$ & .91 & .56 \\
\hline Intergroup bias ${ }^{\mathrm{e}}$ & $2.10(.44)$ & $2.21(.54)$ & $2.15(.49)$ & $2.27(.58)$ & $2.76(.61)$ & $2.51(.64)$ & $9.97 * *$ & $13.87 * * *$ & 3.84 \\
\hline Sexual questioning ${ }^{\mathrm{f}}$ & $2.27(.68)$ & $2.36(.74)$ & $2.32(.71)$ & $2.18(.81)$ & $1.98(.70)$ & $2.08(.76)$ & .18 & $3.49^{*}$ & 1.31 \\
\hline \multicolumn{10}{|l|}{ Psychosocial adjustment } \\
\hline Global self-worth $^{\mathrm{g}}$ & $3.21(.38)$ & $3.11(.41)$ & $3.16(.39)$ & $3.11(.42)$ & $3.17(.39)$ & $3.14(.41)$ & .05 & .07 & 1.14 \\
\hline Social competence ${ }^{\mathrm{h}}$ & $3.01(.39)$ & $2.90(.48)$ & $2.96(.44)$ & $3.03(.34)$ & $3.02(.38)$ & $2.99(.40)$ & .78 & .85 & .55 \\
\hline
\end{tabular}

${ }^{a} 1$ (low gender typicality) 4 (high gender typicality)

${ }^{\mathrm{b}} 1$ (low gender contentedness) -4 (high gender contentedness)

${ }^{\mathrm{c}} 1$ (low levels of experiences of parental pressure to conform to gender stereotypes) 4 (high levels of experiences of parental pressure to conform to gender stereotypes)

${ }^{\mathrm{d}}$ (low levels of experiences of pressure from peers to conform to gender stereotypes) 4 (high levels of experiences of pressure from peers to conform to gender stereotypes)

${ }^{\mathrm{e}} 1$ (low levels of feeling that own sex is superior) 4 (high levels of feeling that own sex is superior)

${ }^{\mathrm{f}} 1$ (very certain about future heterosexual attractions/relationships) -4 (less certain about future heterosexual attractions/relationships)

g 1 (low global self-worth) 4 (high global self-worth)

${ }^{\mathrm{h}} 1$ (low social competence) 4 (high social competence)

${ }^{*} p<.05, * * p<.01, * * * p<.001$

interaction of family type $\mathrm{x}$ all studied gender identity variables and family type $\mathrm{x}$ sexual questioning were entered in Step 3. Table 2 presents the results of the hierarchical regression analyses. Before testing the hypothesis we checked whether there was evidence of multicollinearity between the gender identity variables (gender typicality, gender contentedness, felt parental pressure, felt peer pressure, intergroup bias) and sexual questioning. This was not the case; the tolerance was acceptably (O'Brien 2007) and ranged between .62 and .95 .

Including the studied gender identity variables and sexual questioning in Step 2 produced a significant change in the coefficient of determination $\left(\Delta \mathrm{R}^{2}\right)$ for global selfworth and social acceptance. The interaction terms (family type $\mathrm{x}$ all studied gender identity variables and family type $x$ sexual questioning) in Step 3 did not produce a significant $\Delta \mathrm{R}^{2}$ for global self-worth and social acceptance.

Gender typicality and sexual questioning were independently related to global self-worth and accounted for $15 \%$ of the variance. Children with a high level of gender typicality showed higher levels of global self-worth, and children who questioned future heterosexual romantic involvement reported lower levels of global self-worth. For social competence, gender typicality, gender contentedness and sexual questioning accounted for $35 \%$ of the variance. Children with a high level of gender typicality reported a high level of social competence. Children who were less happy with their assigned gender and were less certain about future heterosexual romantic involvement reported less social competence. For global self-worth and social competence, no significant associations were found for gender of the child and family type.

\section{Discussion}

The results of our study show that children in lesbian families feel less parental pressure to conform to gender stereotypes, are less likely to experience their own gender as superior (intergroup bias), and are more likely to question future heterosexual romantic involvement than children in heterosexual two-parent families. Regardless of whether a child lived in a lesbian or a heterosexual family, gender typicality, gender contentedness and sexual questioning were significant predictors of psychosocial adjustment. As in other studies no associations were found for family type and the children's psychosocial adjustment.

Our findings regarding felt parental pressure to conform to gender stereotypes are in line with the assumption of Stacey and Biblarz (2001) that children of lesbian parents 
Table 2 Summary of hierarchical regression analyses (steps 1,2 and 3) on psychological adjustment.

\begin{tabular}{|c|c|c|c|c|c|c|}
\hline & \multicolumn{3}{|c|}{ Global self-worth ${ }^{\mathrm{i}}$} & \multicolumn{3}{|c|}{ Social competence ${ }^{j}$} \\
\hline & $\mathrm{B}$ & SE & $\beta$ & $\mathrm{B}$ & $\mathrm{SE}$ & $\beta$ \\
\hline \multicolumn{7}{|l|}{ Step 1} \\
\hline Gender $^{\mathrm{a}}$ & -.01 & .07 & -.02 & -.06 & .07 & -.08 \\
\hline Family type $^{\mathrm{b}}$ & -.02 & .07 & -.02 & .07 & .07 & .08 \\
\hline $\mathrm{R}^{2}$ & & & .01 & & & .01 \\
\hline \multicolumn{7}{|l|}{$\Delta \mathrm{R}^{2}$} \\
\hline \multicolumn{7}{|l|}{ Step 2} \\
\hline Gender $^{\mathrm{a}}$ & .03 & .09 & .04 & -.03 & .08 & -.04 \\
\hline Family type $^{\mathrm{b}}$ & -.01 & .07 & .00 & .07 & .06 & .09 \\
\hline Gender typicality $^{c}$ & .21 & .06 & $.32 * * *$ & .36 & .06 & $.54 * * *$ \\
\hline Gender contentedness ${ }^{\mathrm{d}}$ & .10 & .06 & .14 & .13 & .06 & $.20 *$ \\
\hline Parental pressure ${ }^{\mathrm{e}}$ & -.06 & .07 & -.09 & -.10 & .06 & -.16 \\
\hline Peer pressure ${ }^{f}$ & .05 & .06 & .10 & .05 & .05 & .09 \\
\hline Intergroup bias ${ }^{\mathrm{g}}$ & -.03 & .06 & -.05 & .06 & .06 & .08 \\
\hline Sexual questioning ${ }^{\mathrm{h}}$ & -.10 & .05 & $-.19 *$ & -.13 & .04 & $-.24 * *$ \\
\hline $\mathrm{R}^{2}$ & & & $.15^{* *}$ & & & $.35 * * *$ \\
\hline$\Delta \mathrm{R}^{2}$ & & & $.15^{* *}$ & & & $.34 * * *$ \\
\hline \multicolumn{7}{|l|}{ Step 3} \\
\hline Gender & .02 & .09 & .02 & -.04 & .08 & -.04 \\
\hline Family type & .00 & .07 & .00 & .07 & .06 & .08 \\
\hline Gender typicality & .23 & .06 & $.34 * * *$ & .37 & .06 & $.55 * * *$ \\
\hline Gender contentedness & .11 & .07 & .17 & .13 & .06 & $.19 *$ \\
\hline Parental pressure & -.01 & .07 & -.02 & -.09 & .06 & -.13 \\
\hline Peer pressure & .05 & .06 & .09 & .03 & .05 & .06 \\
\hline Intergroup bias & -.06 & .07 & -.10 & .05 & .06 & .07 \\
\hline Sexual questioning & -.11 & .05 & $-.21 *$ & -.15 & .04 & $-.28 * * *$ \\
\hline \multicolumn{7}{|l|}{ Family type $\mathrm{x}$} \\
\hline Gender typicality & -.01 & .13 & -.01 & .03 & .11 & .02 \\
\hline Gender contentedness & .08 & .13 & .06 & -.15 & .11 & -.11 \\
\hline Parental pressure & -.34 & .14 & -.25 & -.10 & .13 & -.07 \\
\hline Peer pressure & .16 & .11 & .16 & -.12 & .09 & -.11 \\
\hline Intergroup bias & .15 & .13 & .10 & .04 & .12 & .03 \\
\hline Sexual questioning & .11 & .10 & .10 & -.02 & .09 & -.02 \\
\hline $\mathrm{R}^{2}$ & & & $.20^{* *}$ & & & $.38 * * *$ \\
\hline$\Delta \mathrm{R}^{2}$ & & & .05 & & & .03 \\
\hline
\end{tabular}

${ }^{\mathrm{a}} 1$ = boys, 2 = girls

${ }^{\mathrm{b}} 1$ = lesbian family, 2 = heterosexual family

${ }^{\mathrm{c}} 1$ (low gender typicality) 4 (high gender typicality)

${ }^{\mathrm{d}} 1$ (low gender contentedness) 4 (high gender contentedness)

${ }^{\mathrm{e}} 1$ (low levels of experiences of parental pressure to conform to gender stereotypes) 4 (high levels of experiences of parental pressure to conform to gender stereotypes)

${ }^{\mathrm{f}}$ (low levels of experiences of pressure from peers to conform to gender stereotypes) 4 (high levels of experiences of pressure from peers to conform to gender stereotypes)

${ }^{\mathrm{g}} 1$ (low levels of feeling that own sex is superior) 4 (high levels of feeling that own sex is superior)

${ }^{\mathrm{h}} 1$ (very certain about future heterosexual attractions/relationships)-4 (less certain about future heterosexual attractions)

${ }^{i} 1$ (low global self-worth)-4 (high global self-worth)

${ }^{\mathrm{j}} 1$ (low social competence)-4 (high social competence)

${ }^{*} p<.05, * * p<.01, * * * p<.001$ 
receive different gender-related information. If this is the case, these children will also develop different ideas about gender than their counterparts in heterosexual families. We could not test whether the connection between family type and parental pressure to conform to gender stereotypes resulted from differences in social structural factors between both family types. This possibility was suggested by Fulcher et al. (2008), who found that division of labour among parents, rather than family type, predicted children's gender stereotypes regarding future occupational choices. In lesbian and heterosexual families in which childcare and paid work outside the home were unequally divided between the two parents, children more frequently opted for future occupational choices characteristic of their gender. In contrast, there were fewer stereotypical occupational choices in children from both lesbian and heterosexual families in which parents shared childcare and paid work outside the home. Fulcher et al. (2008) also found that lesbian mothers have more liberal attitudes than heterosexual parents towards gender-related behaviour among children. Regardless of family type, they also found that if parents hold more liberal attitudes towards gender-related behaviour, their children hold more flexible attitudes towards gender. This might explain our finding that children in lesbian families feel less parental pressure to conform to gender stereotypes.

We also found a main effect of family type on intergroup bias, indicating that children parented by two lesbian mothers are less likely to consider themselves superior to the other gender compared to children in heterosexual families. It is possible that lower levels of pressure experienced from parents to conform to gender stereotypes induce less gender chauvinism in children in lesbian families than their peers of the same gender.

With respect to future heterosexual romantic involvement, it should be borne in mind that the children in the present study were between 8 and 12 years old. We measured their ideas about future heterosexual romantic involvement with the sexual questioning scale developed by Egan and Perry (2001), who used this scale in a study on children in the 4th through 8 th grade. Although almost $2 / 3$ of the children in our study were between 10 and 12 years old we should noted that $1 / 3$ is 8 or 9 years old. Questions about sexual questioning might have a different meaning for these younger children than for the older children, and this might have influenced our findings. On the other hand, sexual questioning already begins at an early age and there is some evidence suggesting that for some children it already occurs by age 10 (Carver et al. 2004; McClintock and Herdt 1996). Furthermore, uncertainty about future heterosexual romantic involvement does not necessarily imply that children will later identify as lesbian, gay or bisexual. On the other hand, our result that children in lesbian families are more likely to be less certain about future heterosexual romantic involvement is in line with the finding of Tasker and Golombok (1997), who showed that young adults raised by lesbian mothers are more likely to consider a same-sex relationship as a valid alternative than those who were raised by heterosexual parents.

Our finding that children in lesbian families are less sure about future heterosexual romantic involvement might be a result of the fact that they grow up in a more tolerant family environment regarding homoerotic relationships. Previous studies have shown that lesbian parents are more sensitive to issues related to their children's sexuality: lesbian mothers feel more comfortable discussing sexuality with their children, and the teenage children of lesbians communicate their feelings more openly to their mothers (Golombok 2000).

Differences related to the gender of the child were evident in all measures of gender identity: boys had higher score than girls on gender typicality, and felt pressure from parents and peers. These findings indicate that boys think more in terms of differential treatment of people according to their biological gender (sex typing) than girls. Conversely, girls scored higher than boys on gender contentedness and exhibited more intergroup bias than boys. These findings are in line with what Egan and Perry (2001) found in their study. They interpreted the boys' higher scores as a consequence of the fact that boys are more sex-typed and also experience more sex typing than girls do. While Egan and Perry (2001) offer no explanation for the finding that girls exhibit more intergroup bias than boys, we assume that this might result from their socially subordinate position, which forces them to oppose to the world of boys in order to maintain their self-esteem. For girls intergroup bias might be a self- protective strategy (Crocker and Major 2003).

We did not find differences between the children in both family types regarding peer pressure to conform to gender stereotypes. This suggests that peers play a similar role in children's acquisition of gender schemas regardless of family background. Nor did we find differences regarding gender typicality and gender contentedness. It might be that these aspects of gender identity are core aspects of children's gender development (Egan and Perry 2001) that develop independently of parental influence. Cognitive development theorists argue that children integrate information about their gender from their wider social environment: they actively construct for themselves what it means to be a boy or a girl (Martin et al. 2004), and it seems that these processes develop independently of the family environment.

Global self-worth was especially predicted by gender typicality and sexual questioning. Social competence was also mostly predicted by gender typicality and sexual 
questioning but in addition also by gender contentedness. We found no significant association between family type and these aspects of psychosocial adjustment. No interactions were found between family type and the studied aspects of gender identity and sexual questioning. Our finding that family type is not associated with psychosocial adjustment - indicating that children in lesbian families and heterosexual families do not differ-supports the "no difference consensus' in empirical research on planned lesbian families (Stacey and Biblarz 2001). That the interactions between family type and gender were not significant indicates that our finding that gender typicality and gender contentedness are generally associated with favourable global self-worth and social competence applies to children in lesbian and heterosexual families. The finding that sexual questioning is associated with unfavourable global self-worth and unfavourable social competence also seems to be independent of whether a child lives in a lesbian or a heterosexual family.

Because children in lesbian families report more sexual questioning and sexual questioning is negatively associated with global self-worth, one would expect children in lesbian families do have lower global self-worth. This does, however, not seem to be the case: we found no difference in global self-worth between children raised in lesbian families compared to children raised in heterosexual families. The idea that sexual questioning might have a differential effect on global self-worth for children in lesbian families and children in heterosexual families is also not supported because children with higher sexual questioning scores have lower esteem in both sorts of families. This inconsistency in our results underscores the need for further research. It could be that sexual questioning is less threatening for children in lesbian families. Children in heterosexual families might associate sexual questioning with sexual deviance. As suggested by other authors sexual questioning adolescents may experience negative reactions such as fear that peers will find out, hoping that their feelings are just a phase, etc. (Dubé et al. 2001); such negative reactions might be less prominent in children raised in lesbian families. Another explanation might be that lesbian parent families offer compensatory strengths that boost self-esteem scores sufficiently to counter negative effects of sexual questioning.

The present study has some limitations. First, it is not clear whether the lesbian mothers were representative of planned lesbian families in general in the Netherlands. To ensure that the sample of planned lesbian families would not be selective, we recruited lesbian mother families in several ways. The lesbian families that participated in our study, however, were relatively well-educated. We compared the planned lesbian mothers in our study with data from a large-scale population survey on sexual behaviour in the Netherlands (Sandfort 1998). Lesbian mothers in our sample did not differ regarding educational level, as assessed in that survey. In addition, no differences were found in our study between the educational level of the lesbian mothers and that of the heterosexual parents.

Secondly, it should be mentioned that this study is a follow-up to an earlier study. The earlier study was conducted four years before the data collection of the follow-up. In both studies, parents in both families types were told that the subject of the study was 'Parenting and child development in different family types'(instead of using the term 'lesbian families'); this to prevent that heterosexual families would not participate in the study because they thought not to belong to the target family group of the survey. Nevertheless, curiosity about the way lesbian parents function might have been an important reason for lesbian couples to participate. Although the cooperation rate for the heterosexual families to participate in this follow-up was lower than for the lesbian families, the response rate was still comparable with that in other Dutch studies on family issues (Brinkman 2000; de Leeuw and de Heer 2002; de Leeuw 2004; Dykstra et al. 2005). Several studies have shown that the non-response rate in household surveys in the Netherlands is relatively high especially compared to other Western countries (Netherlands Official Statistics 1998; de Heer 1999). A nonresponse analysis showed that the families who did not participate in the first study did not differ significantly from the group who participated in the follow up on social demographic variables; nor on quality of parenting, parentchild relationship and children's well-being. Of course, there is still a possibility that there was differential drop out especially among the heterosexual families because parents were briefed that the study was about 'different family types'; and as a consequence it might be that this led to more differences between children in both groups than might be found otherwise.

Another limitation is that our findings are based on the children's answers to interview questions, and the children's responses might have been influenced by social desirability, especially regarding sensitive questions about future heterosexual romantic involvement. However, this is likely to have affected children in both family types equally. Furthermore, our findings are based on relatively small samples sizes. Some prudence is required regarding the fact that we did not find differences between children in planned lesbian families and those in heterosexual families regarding, for example, gender typicality. This might be a result of the lack of statistical power resulting from the small sample sizes. Therefore, future research with larger groups of children in planned lesbian families is recommended.

A further limitation is that we collected data from only one source (children's self-reports). Although this is an improvement on studies that rely solely on parental reports, had we 
obtained information from other sources (e.g. peers and teachers) and used different instruments (e.g. observations), our results may have been different.

Finally, the participants were preadolescents and the study was not longitudinal. A longitudinal study would be especially interesting because it would allow us to understand how the gender identity of children in planned lesbian families develops over time. With a longitudinal design, it would be possible to, for example, assess whether children who have doubts about future heterosexual romantic involvement during their early adolescence have the same doubts at a later phase in their lives and also have more same-sex experiences.

In sum, our findings regarding feeling parental pressure to conform to gender stereotypes, feeling that their gender is superior, and doubting future heterosexual romantic involvement, our findings do not support the 'no difference' consensus in empirical research on lesbian-parent families (Clarke 2002; Stacey and Biblarz 2001). Regarding psychological adjustment, however, our findings do support the no difference consensus.

Acknowledgments The preparation of this manuscript was supported by NIMH center grant P30-MH43520 (P.I.: Anke A. Ehrhardt, Ph.D.) to the HIV Center for Clinical and Behavioral Studies. We are grateful for the help of the students of the department of Education Sciences from the University of Amsterdam for their assistant for data collection.

Open Access This article is distributed under the terms of the Creative Commons Attribution Noncommercial License which permits any noncommercial use, distribution, and reproduction in any medium, provided the original author(s) and source are credited.

\section{Appendix}

Items of scales measuring gender typicality, gender contentedness, feeling pressure from parents/peers to conform to gender stereotypes, intergroup bias, and sexual questioning

All items of the gender identity scales and sexual questioning scale that are used in the present study are provided. Items are from the girls' version of the questionnaire. For gender typicality, gender contentedness, feeling pressure from parents/peers to conform to gender stereotypes, and intergroup bias, the main question was "Can you indicate 'how true of you' each statement is"; the answer categories varied from 1 'not true at all' to 4 'very true'. For sexual questioning the question was "How confident are you that in the future you will ....."; and for the items that followed the answer categories ranged from 1 'not confident at all' to 4 'very confident'. All the items of the sexual questioning scale were reverse scored.
Gender Typicality

1. Ik ben net als alle andere meisjes op mijn leeftijd [I am just like all the other girls at my age]

2. Ik pas goed bij andere meisjes

[I fit in with other girls]

3. Ik ben een goed voorbeeld van een meisje [I am a good example of being a girl]

4. De dingen die ik graag doen in vrije tijd zijn vergelijkbaar met wat de meeste andere meisjes willen doen in hun vrije tijd

[The things a like to do in spare time are similar to what most other girls like to do in their spare time]

5. De dingen waar ik goed in ben zijn vergelijkbaar met waar de meeste meisjes goed in zijn

[The kinds of things that I am good at are similar to what most girls are good at]

6. Mijn persoonlijkheid is vergelijkbaar met de meeste meisjes persoonlijkheid

[My personality is similar to most girls' personality]

Gender Contentedness

1. Ik vind het leuk om een meisje te zijn [I like it being a girl]

2. Ik ben nooit boos als ik dingen moet doen gewoon omdat ik een meisje ben

[I feel never annoyed that I am supposed to do some things just because I am a girl]

3. Ik voel me niet bedrogen wanneer er dingen zijn die moet doen omdat ik een meisje ben

[I never feel cheated that there are things that I am not supposed to do just because I am a girl]

4. Voor wil graag dingen doe die meestal alleen jongens doen [I never wish to do things that usually only boys do]

5. Ik denk nooit dat het wellicht leuker is om een jongen te zijn

[I never think that it might be more fun to be a boys]

6. Ik vind het okay dat sommige dingen alleen voor jongens zijn

[It don't mind that some things are only for boys]

Feeling Pressure from Parents

1. Mijn ouders zouden van streek zijn als iets zou willen leren te doen dat meestal alleen jongens doen

[My parents would be upset if I wanted to learn an activity that only boys usually do]

2. Ik denk dat mijn ouders boos zouden worden als ik zou willen leren vissen

[I think that my parents would be upset if I wanted to learn how to fish] 
3. Mijn ouders zouden het erg als ik zou willen leren om een fiets te repareren

[My parents would mind if I wanted to learn how to fix bicycles]

4. Mijn ouders zouden van streek zijn als ik met jongens speelgoed zou willen spelen

[My parents would be upset if I they wanted to play with boys' toys]

\section{Feeling Pressure from Peers}

1. Andere meisjes die ik ken worden boos wanneer ik ze zou vertellen dat ik met jongens speelgoed zou willen spelen [Other girls I know would be upset if I tell them that I want to play with boys' toys]

2. Andere meisjes die ik ken zouden van streek zijn als ik hen zou vertellen dat iets wil leren te doen dat meestal iets voor jongens is

[Other girls I know would be upset if I tell them that I want to learn an activity that only boys usually do]

3. Andere meisjes die ik ken zouden van streek zijn als ik hen zou vertellen dat ik zou willen leren vissen

[Other girls I know would be upset if I tell them that I want to learn how to fish]

4. Andere meisjes die ik ken zouden het erg vinden als ik hen zou vertellen dat ik wel zou willen leren hoe dat ik een fiets moet repareren

[Other girls I know would be mind if I tell them that I wanted to learn how to fix bicycles]

\section{Intergroup Bias}

1. Meisjes zijn meer te vertrouwen dan jongens

[Girls are more truthful than boys]

2. Jongens zijn saaier dan meisjes

[Boys are more boring than girls]

3. Jongens zijn luier dan meisjes

[Boys are more lazy than girls]

4. Ik word boos wanneer iemand iets slechts over meisjes zegt

[I get upset if someone says something bad about girls]

5. Jongens zijn vervelender dan meisjes

[Boys are more annoying than girls]

6. Meisjes zijn eerlijker dan jongens

[Girls are more honest than boys]

7. Meisjes zijn creatiever dan jongens

[Girls are more creative than boys]

8. Meisjes zijn vriendelijker dan jongens

[Girls are more friendly than boys]
Sexual Questioning

1. trouwen met een man [marry a man]

2. samen met een man een gezin hebben

[have a family together with a man]

3. samenwonen met een man

[live together with a man]

4. samen met een man kinderen hebben

[have a child together with their husband]

5. verliefd zijn op een man

[be in love with a man]

\section{References}

Bandura, A. (1977). Social learning theory. London: Prentice-Hall.

Baumrind, D. (1995). Commentary on sexual orientation: research and social policy implications. Developmental Psychology, 31, 130-136.

Bos, H. M. W., Van Balen, F., \& Van Den Boom, D. C. (2004). Experience of parenthood, couple relationship, social support, and child rearing goals in planned lesbian families. Journal of Child Psychology and Psychiatry, 45, 755-764.

Bos, H. M. W., Van Balen, F., \& Van den Boom, D. C. (2007). Child adjustment and parenting in planned lesbian-parent families. American Journal of Orthopsychiatry, 77, 38-48.

Bos, H. M. W., Gartrell, K., Van Balen, F., Peyser, H., \& Sandfort, Th G M. (2008). Children in planned lesbian families: a crosscultural comparison between the USA and the Netherlands. American Journal of Orthopsychiatry, 2, 211-219.

Brewaeys, A., Ponjaert, I., van Hall, E. V., \& Golombok, S. (1997). Donor insemination: child development and family functioning in lesbian mother families. Human Reproduction, 12, 1349-1359.

Brinkman, J. (2000). De vragenlijst [A questionnaire]. Groningen: Wolter-Noordhoff.

Carver, P. R., Yunger, J. L., \& Perry, D. G. (2003). Gender identity and adjustment in middle childhood. Sex Roles, 49, 95-109.

Carver, P. R., Egan, S. K., \& Perry, G. P. (2004). Children who question their heterosexuality. Developmental Psychology, 40, $43-53$.

Clarke, V. (2001). What about the children? Arguments against lesbian and gay parenting. Women's studies International Forum, 24, 555-570.

Clarke, V. (2002). Sameness and difference in research on lesbian parenting. Journal of Community and Applied Social Psychology, $12,210-222$.

Clarke, V., \& Kitzinger, C. (2004). Lesbian and gay parents on talk shows: resistance or collusion in heterosexism? Qualatitive Research in Psychology, 1, 195-217.

Collaer, M. L., \& Hines, M. (1995). Human behavioural sex differences: a role for gonadal hormones during early development? Psychological Bulletin, 118, 55-107.

Committee on Lesbian Parenthood and Intercountry Adoption. (2008). Rapport interlandelijke adoptie [Report on Intercountry Adoption]. Den Haag: Ministery of Justice.

Crocker, J., \& Major, B. (2003). The self-protective properties of stigma: evolution of a modern classic. Psychological Inquiry, 14, 232-237. 
de Heer, W. (1999). International repsonse trends: Results of an international survey. Journal of Official Statistics, 15, 129-142.

de Leeuw, E. (2004). Non-response en panelonderzoek: Voorkomen is beter dan genezen [Non-response and panel surveys: how to prevent this]. Facta, 1, 28-30.

de Leeuw, E., \& de Heer, W. (2002). Trends in Household survey nonresponse: a longitudinal and international comparison. In R. M. Groves, D. A. Dillman, D. A. Dillman, J. L. Eltinge \& R. J. A. Little (Eds.), Survey non-response (pp. 41-54). New York: Willey.

Dubé, E. M., Savin-Williams, R. C., \& Diamond, L. M. (2001). Intimacy development, gender, and ethnicity among sexualminority youths. In A. R. D'Augelli \& C. J. Patterson (Eds.), Lesbian, gay, and bisexual identities and youth (pp. 129-152). New York: Oxford University Press.

Dykstra, P. A., Kalmijn, M., Knijn, T. C. M., Komter, A. E., Liefboer, A. C., \& Muldrer, C. H. (2005). Codebook of the Netherlands kinship panel study: A multi-actor, Multi-method panel study on solidarity in family relationships. Wave 1. The Hague: Netherlands Interdisciplinary Demographic Institute.

Egan, S. K., \& Perry, D. G. (2001). Gender identity: a multidimensional analysis with implications for psychosocial adjustment. Developmental Psychology, 37, 451-463.

European Commission, E. (2006). Eurobarometer 66. Public opinion in the European Union. First results. Brussel: European Commission.

Fulcher, M., Sutfin, E. L., \& Patterson, C. (2008). Individual differences in gender development: associations with parental sexual orientation, attitudes, and division of labor. Sex Roles, 58 , $330-341$.

Gallup Poll. (2009). Gay and lesbian rights. Retrieved from http:// www.gallup.com/poll/1651/Gay-Lesbian-Rights.aspx.

Golombok, S. (2000). Parenting. What really counts. London: Routledge.

Golombok, S., \& Tasker, F. (1996). Do parents influence the sexual orientation of their children? Findings from a longitudinal study of lesbian families. Developmental Psychology, 32, 3-11.

Golombok, S., Spencer, A., \& Rutter, M. (1983). Children in lesbian families and single parent households: psychosexual and psychiatric appraisal. Journal of Child Psychology and Psychiatry, 24, $551-572$

Golombok, S., Perry, B., Burston, A., Murray, C., Mooney-Somers, J., Stevens, M., et al. (2003). Children with lesbian parents: a community study. Developmental Psychology, 39, 20-33.

Green, R., Mandel, J., Hotvedt, M., Gray, J., \& Smith, L. (1986). Lesbian mothers and their children: a comparison with solo parent heterosexual mothers and their children. Archives of Sexual Behavior, 15, 167-184.

Harter, S. (1985). The perceived competence scale for children. Child Development, 53, 87-97.

Hofstede, G. (1998). Masculinity/femininity as a dimension of culture. In G. Hofstede (Ed.), Masculinity and femininity: The taboo dimension of national cultures (pp. 3-38). Thousand Oaks: Sage.

Iervolino, A. C., Hines, M., Golombok, S., Rust, J., \& Plomin, R. (2002). Genetic and environmental influences on sex-typed behavior in pre-school children: a study of 2, 434 same-sex twin pairs at 3 and at 4 years of age. Child Development, 76, $826-840$.

Kelley, J. (2001). Attitudes towards homosexuality in 29 nations. Australian Social Monitor, 4, 15-21.

Lippa, R. A. (2002). Gender, nature and nurture. Mahwah: Erlbaum.

Lubbers, M., Jaspers, E., \& Ultee, W. (2009). Primary and secondary socialization impacts on support for same-sex marriage after legalization in the Netherlands. Journal of Family Issues. Advance online publication . doi:10.1177/0192513X09334267.

MacCallum, F., \& Golombok, S. (2004). Children raised in fatherless families from infancy: a follow-up of children and single heterosexual mothers at early adolescence. Journal of Child Psychology and Psychiatry, 45, 1407-1419.

Maccoby, E. E. (1998). The two sexes: Growing up apart, coming together. Cambridge: Harvard University Press.

Martin, C. L. (2000). Cognitive theories of gender development. In T. Eches \& H. Trautner (Eds.), The developmental social psychology of gender (pp. 91-121). Mahwah: Erlbaum.

Martin, C. L., Ruble, D. N., \& Szykrybalo, J. (2004). Recognizing the centrality of gender identity and stereotype knowledge in gender development and moving toward theoretical integration: reply to Bandura and Bussey (2004). Psychological Bulletin, 130, 702-710.

McClintock, M. K., \& Herdt, G. (1996). Rethinking puberty: the development of sexual attraction. Current Directions in Psychological Science, 5, 178-183.

Netherlands Official Statistics. (1998). Special issue. Integration of household surveys; Design, advantages and methods. Voorburg/ Heerlen: Statistiscs Netherlands.

O'Brien, R. M. (2007). A caution regarding rules of thumb for variance inflation factors. Quality and Quantity, 41, 673-690.

Sandfort, Th. (1998). Homosexual and bisexual behaviour in European countries. In M. Hubert, N. Bajos \& Th Sandfort (Eds.), Sexual behaviour and HIV/AIDS in Europe (pp. 68-106). London: UCL.

Sandfort, Th. (2000). Homosexuality, psychology, and gay and lesbian studies. In T. Sandfort, J. Schuyf, J. W. Duyvendak \& J. Weeks (Eds.), Lesbian and gay studies. An introductory, interdisciplinary approach (pp. 14-45). London: Sage.

Sandfort, Th., McGaskey, G. M., \& Bos, H. M. W. (2008, July). Cultural and structural determinants of acceptance of homosexuality: a cross-national comparison. Paper presented at the International Congress of Psychology, Berlin, Germany.

Stacey, J., \& Biblarz, T. J. (2001). (How) Does the sexual orientation of parents matter? American Sociological Review, 66, 159-183.

Tasker, F. L., \& Golombok, S. (1997). Growing up in a lesbian family. Effects on child development. New York: Guilford.

Tenenbaum, H. R., \& Leaper, C. (2002). Are parents' gender schemas related to their children's gender-related cognitions?: a meta analysis. Developmental Psychology, 38, 615-630.

Van de Meerendonk, B., Eisinga, R., \& Felling, A. (2003). Application of Herek's attitudes toward lesbians and gay men scale in the Netherlands. Psychological Reports, 93, 265-275.

Van de Meerendonk, B., \& Scheepers, P. (2004). Denial of equal civil rights for lesbians and gay men in the Netherlands, 1980-1993. Journal of Homosexuality, 47, 63-80.

Van den Bergh, B. R. H., \& Marcoen, A. (1999). Harter's selfperception profile for children: factor structure, reliability, and convergent validity in a Dutch-speaking Belgian sample of fourth, fifth and sixth graders. Psychologica Belgica, 39, 29-47.

Vonk, M. (2004). One, two or three parents? Lesbian co-mothers and a known donor with 'family life' under Dutch law. International Journal of Law, Policy and the Family, 18, 103-117.

Whitley, B. (2009). Religiosity and attitudes toward lesbians and gay men: a meta-analysis. The International Journal for the Psychology of Religion, 19, 21-38.

World Value Survey. (2005). WVS 2005. Codebook. Retrieved from http://www.worldvaluessurvey.org. 